\title{
Impact of Work from Home on Employee Satisfaction: An Empirical Study on Bangladesh
}

\author{
Fariya Tabassum Ritu Rani Sarker \\ BBA and MBA, Department of Management, University of Dhaka
}

\begin{abstract}
This study is based on working from home and the aim is to assess the impact that working from home has on employee satisfaction within the organizations of Bangladesh. Additionally, the purpose is to address the variable's effects (flexibility, perceived autonomy \& work-family balance, etc.) on the relationship between work from home and job satisfaction. As a result, this study focuses light on current insight into employees' attitudes of work from home along with its outcomes. A total of 68 employees participated in the study, which based on an online survey, and findings are mainly attained through primary data. This study will beneficial for the HR department of the organizations, policymaker, and future students because through this study they can find out the concept of the work from home and the impact of work from home that affects the employee's satisfaction.
\end{abstract}

Keywords: Work from Home (WFH), Satisfaction, Flexibility, Autonomy, and Work-life Balance.

DOI: $10.7176 /$ RJFA/12-17-01

Publication date:September $30^{\text {th }} 2021$

\section{Introduction}

In this epidemic (Covid-19), working from home has become a major concern for almost all organizations. Although It (WFH) is a new concept in Bangladesh, many organizations in our country (both private and public) are incorporating this into their work. Homework is a progressive pattern in the current job, where employees can undoubtedly be able to move from wherever they are (Sarma \& Medhi, 2020). Working from home affects many things around the world which is sure to be the best way forward. Because of the flexible workforce they tend to be happier and more loyal employees (Sunday, 2015). Now work-at home is a necessity for the situation. These days, the vast majority of companies offer this option to its employees' affecting job satisfaction (Khan, 2019). Working from home can eliminate headaches and problems associated with commuting to work, and employees can devote more time to work-related tasks without wasting time on transportation (Sarma and Medhi, 2020). It has shown that domestic workers have more control over their workplace and personal health. WFH reduces the frequent conflicts that occur between work and family life, also helping to manage children that create a work-life balance (Khan, 2019). Many studies have found that employees have a strong, positive satisfaction with the flexibility of working at home. Allowing employees to choose where and how they work can increase employee loyalty and job satisfaction, and can reduce profits (White, 2015). Employees who had work at home faced a high level of job satisfaction. It was understood that some telephone operators received higher levels of job satisfaction than others. Personality and personality, it provides greater insight into ethics and work satisfaction (Smith, Patmos, Pitts, 2018). The ability to work part-time at home has been recognized by employees as a positive aspect of the job that provides a flexibility to balance work commitment and unemployment. (Dockery and Bawa, 2014).

In this study, an attempt was made to show the relationship between work from home and employee satisfaction in Bangladesh. By identifying relationships, some ideas are explored by simple analysis and several linear analyzes.

\subsection{Literature Review}

2.1 Works from Home

Homework can be particularly defined in the daily routine of travel (Reynolds, 2011) Homework is a highperformance online and offline work environment with a variety of tasks regardless of the physical location of each task. Working from home is sometimes called Long Work or working from home which suggests that workers work in a remote area usually at home. Homework is where employees can do their homework (Khan, 2019). It is widely known as a form of flexibility because of the way it gives employees the opportunity to work with flexibility to do parts of their work within the workplace; this can include when they work (Dizaho et al., 2017).

\subsection{Works from Home and Employee Satisfaction}

Working from home supports a variety of sustainability programs, from economic growth and reduced inequality to sustainable cities, climate change, and sustainable use. For employees to see that they are contributing to society by reducing land and carbon pollution that creates the effect of heat (Courtney, 2020). Many employees 
had strong, positive satisfaction with the flexibility of working from home. Management results also look good (Sunday 2015). Allowing employees to choose where and how they work can increase employee loyalty and job satisfaction, and can reduce profits (White, 2015). If employees have health problems that lead to them needing special office equipment, they can set up their home office which means a custom office. Working out in a variety of ways: more time for exercise, the ability to recover from illness or surgery at home, the ability to eat healthily, the ease of caring for a health or disability issue, slow exposure to disease, easy-care for a health or disability problem, and the option to build a comfortable and ergonomic workplace. It enhances the commitment of employees to their organization that leads to employee engagement, increases productivity, satisfaction, and performance (Courtney, 2020). Employees feel motivated as they find a balance of good working life, and improve their efficiency. Moreover, it likewise causes the organization to complete the task (Khan, 2019). No relationship was found at how several years felt about the fulfillment of the task. There was ample evidence to suggest that there was a significant difference in employee satisfaction levels over many years in the various job groups. The level of use of technology does not affect the level of job fulfillment separately for many years (Tabane, 2011). There were traffic problems so the representatives should be considered to work from home which was to choose the job of choice. Most of the workers were recruited from work from houses. It has been useful to reduce the hourly traffic. The various components of homework also show a few variables that affect employees' tendency to work from home. Some of the factors influenced the decision to get to work from home mode. As with all items such as individual and family unit, work-related, travel-related has a significant impact on performance from home selection (Ismail, Hamsa \& Mohamed, 2012).

Schall (2019) learned that the relationship between remote performance levels and levels of employee satisfaction in the workplace. Significant changes were independence, the conflict between work and family, and the power of telecommuting. In the study, 185 employees participated in the online survey. Diversity affects job satisfaction. The results showed a consistent relationship between working at home with a positive relationship and job satisfaction. A key finding of the study is that working from home can be an effective way to increase job satisfaction levels. Because remote work influences employees to have less conflict in the work-family (WFC), higher visual independence, lower pressure, and greater intensity of telecommuting create job satisfaction. Virtual work connects with reliable, purpose-oriented operations that work on a regular basis, space and organizational boundaries through reinforced links reinforced by book development networks and job satisfaction is a desirable state of love in their work.

From the above discussion, the basic hypothesis can be developed. So, the hypothesis is-

$\mathbf{H}_{1}$ : There is a positive relationship between work from home (WFH) \& employee satisfaction.

In addition, the article 'Factors Affecting Job Satisfaction and the Effects of Real Workforce Work', investigated the constant interaction of visible workers. He was accustomed to a guaranteed discharge within the visible workplace. His motive was to investigate the previous encounters of visible experts and therefore he was an engaging participatory researcher. Work, Workplace, Health Equality, Training, Technical Support, Communication, and Adaptability create the result of Job's satisfaction (Regina, 2016). Many organizations or associations have faced unique experiences with difficulties, problems, and strategies. The author was taught the transition from representatives of working life to job satisfaction. He was specified in two sections; the first reflected the advancement in the visual office from the four perspectives, therefore, communication, social relations, recognition of achievement, and the balance of work-life; and the second was to find the effect of the life of the work you spoke of on the fulfillment of the work. (Zhang, 2016). In addition to the general business downturn also, working from home improves performance and satisfaction compared to office work. In China, companies have allowed employees to work from home to reduce the number of employees, increase productivity and job satisfaction. In addition to improving the working life balance, working from home can reduce corporate costs and benefit communities by reducing traffic congestion and commuters. (Bloom, 2015). Working from home provides a way for greater work intervention in family life and work-related stress. The document concludes that the ability to work part-time from home is recognized by employees as a positive aspect of the job that provides flexibility to balance work commitment and unemployment. (Dockery and Bawa, 2014). Telecommuting does not blur the line between work and family. Workers cost less work, and work continues to be accomplished at home at the same rate. According to this study, Working from home does not affect work relationships as long as managers are on board and good communication channels exist. Employees who maintain regular contact with management and colleagues over the phone or email have seen improved working relationships. It also increases employee engagement and productivity (Pennsylvania State University, 2020).

Under this discussion some sub hypotheses can be developed. So these ares-

- $\quad \mathbf{h}_{1}$ : There is a positive relationship between work from home $\&$ flexibility in time/schedule.

- $\quad \mathbf{h}_{2}$ : There is a positive relationship between work from home \& work-life balance.

- $\quad \mathbf{h}_{3}$ : There is a positive relationship between work from home \& lower stress.

h4: There is a positive relationship between work from home \& autonomy in personal life and work place. 
A challenging aspect of working from home for parents of young children is managing children. And low-paying jobs tend to be more personal and collaborative and therefore less efficient. So you find that the highest paid people can work from home. Low-income people will lose their income (Bloom, 2020). Employees, with better education and higher wages, often decide to work from home. Young children are also negatively associated with work effort. Longevity and age have a negative impact on work effort and satisfaction (Rupietta \& Beckmann, 2016). Homework is often claimed to affect work progress, which may have a negative impact on overall job satisfaction. Such claims were usually based on studies of manager positions and not on direct evidence of the benefit of home-based workers (Tolbert and Simons, 1994).

From this above discussion, some sub hypothesis can be developed. Those are-

- $\quad \mathbf{h}_{5}$ : There is a relationship between work from home \& difficulty in monitoring performance.

- $\quad \mathbf{h}_{6}$ : There is a relationship between information security risk \& work from home.

- $\quad \mathbf{h}_{7}$ : There is a relationship between work from home \& communication problem.

In this pandemic situation of (Covid-19), work from home is a new concept in Bangladesh. Many organizations (both private \& public) introduce this in their work place. In existing literature, all researchers had shown the study in foreign country perspective. As it is a new concept for the country so there is a few researches about this issue in Bangladesh. So in this study, it has been tried to show the relation between work from home and employee satisfaction in Bangladesh.

\subsection{Conceptual Framework}

In this study, this analytical tool expresses the relationship between work from home (Independent variable) and employee satisfaction (dependent variable). Under the independent variables some variables are flexibility, work-life balance, and lower stress, difficulty in monitoring performance, information security risk, communication problems, and autonomy.

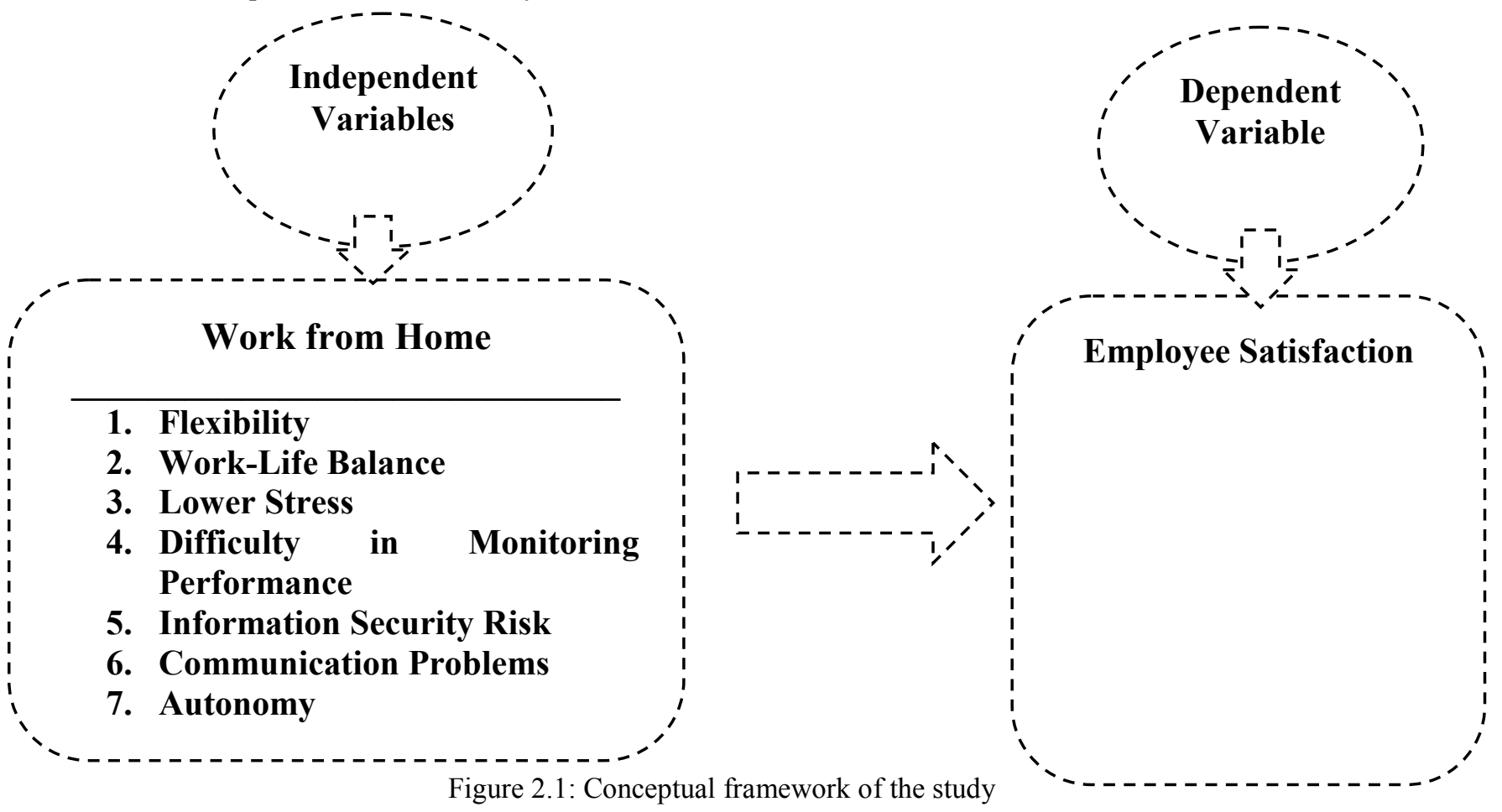

\subsection{Methodology}

On the basis of purpose, this research is causal research because its shows the relationship between work-from home and employee's satisfaction. Mixed approach has been used in this research. The study design can be named as cross-sectional study because the number of contacts with the respondents has been occurred in one time. The data needed for conducting the report has been collected from the primary sources and secondary sources. Primary Sources consist by conducting survey through Questionnaire. Secondary Sources consist by Journal articles, Websites, Different books, papers, manuals etc. related to the topic. 


\begin{tabular}{|c|c|c|c|c|}
\hline $\begin{array}{c}\text { Dependent } \\
\text { Variable }\end{array}$ & Independent Variables & Variable Items & $\begin{array}{l}\text { No. of } \\
\text { items }\end{array}$ & References \\
\hline \multirow{9}{*}{$\begin{array}{l}\text { Employee } \\
\text { Satisfaction }\end{array}$} & Flexibility & & & $\begin{array}{l}\text { (Sarma \& Medhi, } \\
\text { (Regina, 2016); } \\
\text { \&Kelley, 2015) }\end{array}$ \\
\hline & \multirow[b]{2}{*}{ Work-Life Balance } & Managing Children & \multirow[b]{2}{*}{2} & \multirow{2}{*}{$\begin{array}{l}\text { (Schall, 2019); (Bloom, 2020); } \\
\begin{array}{ll}\text { (Dawson, } & \text { 2020); } \\
\text { 2019); } & \text { (Zhang, 2016); } \\
\text { (Rupietta\& Beckmann, 2016) }\end{array}\end{array}$} \\
\hline & & $\begin{array}{l}\text { Reducing Work-Family } \\
\text { Conflict }\end{array}$ & & \\
\hline & Lower Stress & & & $\begin{array}{c}\text { (Zhang, 2016); (Rupietta\& } \\
\text { Beckmann, 2016) }\end{array}$ \\
\hline & $\begin{array}{c}\text { Difficulty in Monitoring } \\
\text { Performance }\end{array}$ & & & $($ Bloom,2020) \\
\hline & $\begin{array}{c}\text { Information Security } \\
\text { Risk }\end{array}$ & & & (Church, 2015) \\
\hline & $\begin{array}{c}\text { Communication } \\
\text { Problems } \\
\end{array}$ & & & (Kiss,2020) \\
\hline & \multirow[t]{2}{*}{ Autonomy } & $\begin{array}{c}\text { Autonomy in Personal } \\
\text { life }\end{array}$ & \multirow[t]{2}{*}{2} & \multirow[t]{2}{*}{$\begin{array}{c}\text { (Schall, 2019); (Dawson, } \\
\text { 2020) }\end{array}$} \\
\hline & & $\begin{array}{c}\text { Control over the Work } \\
\text { Environment }\end{array}$ & & \\
\hline
\end{tabular}

Table 3.1: Dependent and Independent variables

\subsection{Questionnaire Design}

Questionnaire is mainly designed to collect the primary data. In this study, questionnaire has been divided into three sections. First section covers demographic/personal information. Second section covers the information about the impact of work from home (WFH) on employee satisfaction. And finally third section covers recommendations or suggestions regarding this issue. The questions included in questionnaire has been designed both open and close ended questions. The close ended questions have been made based on the likert scale or summated rating. Five scaling measurement has been used in likert scale.

\subsection{Population and sampling}

Here, Population size is the number of official's staffs of the five several organizations where 'works from home' policy is practiced. The sum total of the officials is the population size. The distribution of population size is given below:

\begin{tabular}{|l|l|}
\hline Name of the institution & Number \\
\hline Grameenphone & 2300 \\
\hline Banglalink & 1100 \\
\hline Meghna Group of Industries (Head Office) & 800 \\
\hline Private University ( Northern University) & 86 \\
\hline Private Bank (Dutch-Bangla Bank Limited) & 500 \\
\hline Total & 4786 \\
\hline
\end{tabular}

Table 3.2: Population Distribution

So, Population $(\mathrm{N})=4786$

Sample size has been derived by the following formula-

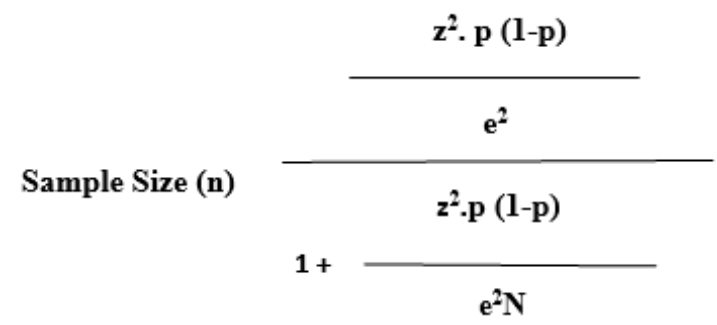

Figure: Sample Size Determination Formula

Here, the margin of error $(e)=0.10, p=.50 \&$ critical value of the normal distribution at the $90 \%$ confidence level, $Z=1.65$ has been estimated.

According to formula, the result is 68(Sample size 68). This means 68 surveys are needed to have a 
confidence level of $90 \%$ that the real value is within $+/-10 \%$ of the measured/surveyed value. For sampling, convenient random sampling method has been used.

\subsection{Data Analysis tools}

In this study, for analyzing data descriptive statistics (Mean, Standard Deviation \& Percentage), Reliability Analysis, Pearson Correlation, Simple \& Multiple Linear Regression have been used. Simple Regression has been used for testing basic hypothesis and Multiple Linear Regression has been used for identifying the significance of sub hypothesis. For analyzing the data, SPSS version 25 has been used.

Multiple Linear Equation: $\mathrm{Y}=\mathrm{A}+\mathrm{B}\left(\mathrm{X}_{1+}\right.$ $\left.+\mathrm{X}_{7}\right)$

Here, $\mathrm{Y}($ Dependent Variable $)=$ Employee Satisfaction

$\mathrm{A}=$ Fixed Cost; $\quad \mathrm{B}=$ Slope

$\mathrm{X}_{1}$ (Independent Variable) $=$ Flexibility, $\mathrm{X}_{2}$ (ID) $=$ Work-Life Balance, $\mathrm{X}_{3}$ (ID)= Lower Stress, $\mathrm{X}_{4}$ (ID) $=$ Difficulty in Monitoring Performance, $X_{5}$ (ID)=Information Security Risk, $X_{6}$ (ID)=Communication Problems , $\mathrm{X}_{7}(\mathrm{ID})=$ Autonomy.

For qualitative analysis historical method has been used for creating literature review. It describes past events in order to understand present patterns and anticipate future choices. In this study, Content analysis has also been used.

\subsection{Ethical Considerations}

Ethical considerations that needed to be taken into account, however, all participants were made aware that any information they provide would be held strictly confidential and keeping participant's responses anonymous and unidentifiable would remain. No modification has been made and was very appreciate of all literature that has contributed in any way to this study. In addition to this it was ensured that all data provided by participants was held and looked after correctly to ensure that no one else got hold of the data or that the data was lost or destroyed incorrectly.

\subsection{Analysis of the Study}

4.1 Sample Characteristics

This section expresses the demographic characteristics of the participants.

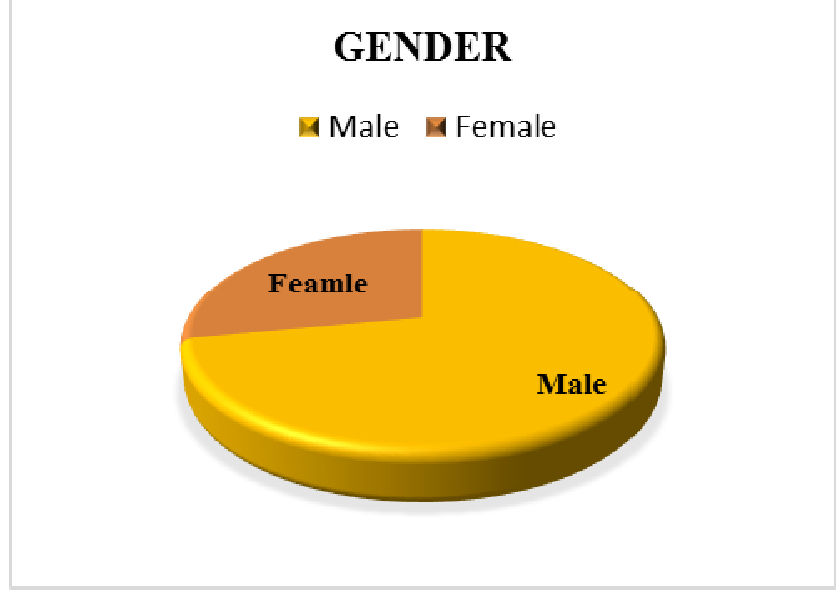

Figure 4.1: Shows the gender of the respondents

Among the respondents $72 \%$ is male and $28 \%$ is the female and $44 \%$ of the participants are between the ages of $25-40.35 \%$ is between the ages of $41-50$ and $21 \%$ of the respondents are between the ages of 51-60 which are shown in the above figure.

\subsection{Descriptive Statistics \& Reliability Analysis}

The score of mean, standard deviation and Cronbach's Alpha are summarized in the following Table 5.1. The table also shows the number of items used for assuring each dimension (the mean, standard deviation, \& Alpha score) that helps to analyze the perception of respondents about study variables.

Results of descriptive analysis (Table 5.1) instituted moderate to high scores of mean for all variables used in this study varying between 3.33 and 4.31 . 
Table 4.1: Shows the summary of Descriptive \& Reliability Statistics

\begin{tabular}{|c|c|c|c|c|}
\hline \multicolumn{1}{|c|}{ Variables } & Mean & $\begin{array}{c}\text { Standard Deviation } \\
\text { (SD) }\end{array}$ & $\begin{array}{c}\text { Alpha } \\
\text { No. of } \\
\text { items }\end{array}$ \\
\hline Work from home & 4.3109 & .526 & 0.872 & 9 \\
\hline 1. Flexibility & & .765 & & \\
\hline 2. Work life balance & 4.1364 & .570 & 0.765 & 2 \\
\hline 3. Lower Stress & 4.0000 & .764 & & \\
\hline 4. Difficulty in Monitoring Performance & 3.7955 & 4.0909 & .190 & \\
\hline 5. Information Security Risk & 3.8409 & .745 & & \\
\hline 6. Communication Problems & 3.3318 & .661 & & \\
\hline 7. Autonomy & 4.1564 & .521 & 0.814 & 2 \\
\hline Employee satisfaction & 4.0182 & .195 & 0.921 & 10 \\
\hline
\end{tabular}

Among 68 respondents almost 78\% indicates that there is a positive relationship between work from home \& flexibility in time/schedule. The mean is 4.13 \& SD is .765 (table 5.1). Mean is the average of all the data points. According to Likert scale interval range, it means that the majority of respondents are agreeing. For identifying the relationship between work from home \& work-life balance, respondents have been asked about the two items. Those are managing children $(\mathrm{M}=4.05) \&$ reducing work family conflict $(\mathrm{M}=4.34)$. And $73 \%$ says positive relationship among work from home, managing children \& reducing work family conflict. This two items are moderately reliable (Alpha $=.765)$ that is identified by the Alpha scores. The mean of work life balance is $4.00 \&$ standard deviation is .57060 (table 5.1). It indicates work from home helps to managing children \& reducing work family conflict that create employee's work-life balance. The impact of work from home for creating lower stress is moderate (From table 5.1: $\mathrm{M}=3.79 \& \mathrm{SD}=.764$ ). There is a difficulty in monitoring performance at the time of work from home $(\mathrm{M}=4.09 \& \mathrm{SD}=0.19)$. The relationship among work from home, information security risk \& communication problem is moderate because the scores of mean are $3.84 \& 3.33$. In the context of autonomy, respondents are asked about the autonomy in personal life \& work place. And these two items produce the greatest alpha coefficient is 0.814 . All these variables are the items of work from home \& the mean (4.31) indicates that these variables positively affect WFH. And the greatest value of alpha $=0.87$ (Table 5.1). For identifying the satisfaction level ten items are used which produce the greatest alpha coefficient (0.921). That indicates there is a significant consistency \& reliability among those items. The respondents' ratings of their overall satisfaction were moderately high $(\mathrm{M}=4.018, \mathrm{SD}=.19)$.

\subsection{Pearson Correlation}

Pearson correlation is experimented to explore the standard relationship among the study variables.

Table 4.2: Shows the correlation among variables

\begin{tabular}{|c|c|c|c|c|c|c|c|c|c|}
\hline Items & WFH & F & WLB & LS & DM & ISR & CP & A & ES \\
\hline Work from Home & 1 & & & & & & & & \\
\hline Flexibility (F) & .292 & 1 & & & & & & & \\
\hline Work life balance (WLB) & .279 & .650 & 1 & & & & & & \\
\hline Lower Stress (LS) & .242 & .190 & .053 & 1 & & & & & \\
\hline $\begin{array}{c}\text { Difficulty in Monitoring } \\
\text { Performance (DM) }\end{array}$ & $.875^{* *}$ & .185 & -.166 & .027 & 1 & & & & \\
\hline $\begin{array}{c}\text { Information Security Risk } \\
\text { (ISR) }\end{array}$ & $.334^{*}$ & -.002 & -.055 & -.146 & .036 & 1 & & & \\
\hline $\begin{array}{c}\text { Communication Problems } \\
\text { (CP) }\end{array}$ & -.150 & -.027 & .092 & -.074 & $-.416^{* *}$ & .072 & 1 & & \\
\hline Autonomy (A) & $.341^{*}$ & -.048 & .020 & .188 & .055 & $.476^{* *}$ & .163 & 1 & \\
\hline Employee Satisfaction & .086 & .172 & $.344^{*}$ & .083 & -.087 & -.100 & -.044 & .310 & 1 \\
\hline
\end{tabular}

* Correlation is significant at the 0.05 level (2-tailed)

** Correlation is significant at the 0.01 level (2-tailed)

As exhibited in Table 5.2, the result of correlation reveals that there is a both positive \& negative relationship among variables. The relationship among work from home, flexibility \& work life balance had a moderately positive, significant relationship $(r)=(0.292,0.279,0.242)$ such that WFH gives enough flexibility in time, helps to create work-life balance \& lower stress. Flexibility is considerably correlated with work-life balance $(0.650, p<0.01)$, lower stress $(0.190)$, difficulty in monitoring performance $(0.185, p<0.01) \&$ negatively correlated with information security risk (-.002), communication problems (-.027) \& autonomy (-.048). WLB is 
significantly correlated with employee satisfaction $(\mathrm{r}=0.344, \mathrm{p}<0.05)$. Lower stress has moderately positive correlation with employee satisfaction (0.083). Difficulty in monitoring performance and communication problems has negative relationship with each other $(-.416, \mathrm{p}<0.01)$. Both are negatively correlated with employee satisfaction $(-.087,-.044)$. Work from home highly correlated $(0.875, \mathrm{p}<0.01)$ with difficulty in monitoring performance. And difficulty in monitoring performance negatively correlated with satisfaction $(\mathrm{r}=$ .087). Such that work from home create difficulty in monitoring performance. Communication problem and work from home are negatively correlated $(\mathrm{r}=-.150)$. That indicates WFH does not create communication problems. WFH and information security risk significantly correlated with each other $(0.334, \mathrm{p}<0.05)$.Information security risk highly correlated with autonomy $(0.476, \mathrm{p}<0.01)$ \& negatively correlated employee satisfaction $(-.100)$. Such that works from home create information security risk. Work from home positively correlated with autonomy $(0.341, \mathrm{p}<0.05)$ and autonomy also significantly correlated with employee satisfaction $(0.310, \mathrm{p}<0.01)$. From the above Table 5.2, work from home and employee satisfaction had a moderately positive, significant relationship, $\mathrm{r}=0.086$. That indicates WFH creates employee satisfaction.

\subsection{Test of Hypotheses}

Although correlations statement (Table 5.2) evidenced significant relationship between work from home (WFH) and employee satisfaction, simple and multiple regressions were also tested to better understand the significance of this relationship determining work from home (WFH) as independent and employee satisfaction as dependent variable. Outcomes of simple and multiple regressions have been presented in Table 5.3 and table 5.4 respectively. As shown in Table 5.3, the result of simple regression expresses that work from home significantly related to the employees' satisfaction $(\beta=0.386$, sig $=0.000, \mathrm{p}<0.01)$. So, the basic hypothesis $\left(\mathrm{H}_{1}\right)$ is accepted that denotes there is a positive relationship between work from home and employee satisfaction. The impact of this relationship is moderately high as the value of $\mathrm{R}^{2}=.043$, which indicates $43 \%$ of the variance employee's satisfaction.

Table 5.3: Result of Simple Regression Analysis

\begin{tabular}{|c|l|l|l|l|l|l|}
\hline Hypothesis & Independent Variable & Dependent Variable & $\mathbf{R}^{\mathbf{2}}$ & Beta $(\boldsymbol{\beta})$ & Sig. & Result \\
\hline $\mathbf{H}_{\mathbf{1}}$ & Work from home & Employee satisfaction & 0.43 & 0.386 & 0.000 & Accepted \\
\hline
\end{tabular}

Table 4.3: Result of Multiple Regression Analysis

\begin{tabular}{|c|l|l|l|l|l|l|}
\hline Hypothesis & Independent Variable & Dependent Variable & $\mathbf{R}^{\mathbf{2}}$ & Beta $(\boldsymbol{\beta})$ & Sig. & Results \\
\hline $\mathbf{h}_{\mathbf{1}}$ & Flexibility in time/schedule & \multirow{5}{*}{} & & 0.367 & 0.027 & Significant \\
\hline $\mathbf{h}_{\mathbf{2}}$ & Work-life balance & & 0.452 & 0.041 & Significant \\
\hline $\mathbf{h}_{\mathbf{3}}$ & Lower stress & & 0.372 & 0.040 & Significant \\
\hline $\mathbf{h}_{\mathbf{4}}$ & Autonomy & \multirow{5}{*}{ Employee satisfaction } & \multirow{4}{*}{0.50} & 0.467 & 0.000 & Significant \\
\hline $\mathbf{h}_{\mathbf{5}}$ & Monitoring performance & & 0.572 & 0.007 & Significant \\
\hline $\mathbf{h}_{\mathbf{6}}$ & Information security risk & & 0.123 & 0.025 & Significant \\
\hline $\mathbf{h}_{\mathbf{7}}$ & Communication problem & & 0.582 & 0.635 & Not accepted \\
\hline
\end{tabular}

Through the analysis of multiple regressions, Table 5.4 illustrates the impact of seven constructs of work from home $(\mathrm{WFH})$ on employee satisfaction. Results indicate that factors of WFH namely flexibility in time/schedule $(\beta=0.367$, Sig=0.027), work-life balance $(\beta=0.452, \operatorname{Sig}=0.041, p<0.05)$, lower stress $(\beta=0.372$, Sig=0.040), autonomy $(\beta=0.467$, Sig=0.000, $\quad \mathrm{p}<0.01)$, monitoring performance $(\beta=0.572, \quad$ Sig=0.007, $\mathrm{p}<0.01)$, information security risk $(\beta=0.123$, Sig $=0.025, \mathrm{p}<0.05)$ have significant impact on employee satisfaction. So, WFH increases flexibility, work-life balance, lower stress \& autonomy that indicate employee satisfaction. And there is a difficulty in monitoring performance \& increases information security risk at the time of work from home. On the other hand, communication problem $(\beta=0.582, \operatorname{Sig}=0.635, p<0.01)$ has no significant impact on employee satisfaction.

\section{Discussion}

Homework is becoming more and more common due to the increase in technology in the workplace (Caramela, 2017). Therefore, the purpose of the current study was to find a relationship between work from home and employee satisfaction among professionals. Specifically, the aim was to address the changing outcomes (Table 2.1: flexibility, perceived independence \& balance of family work, etc.) in the relationship between work from home and work satisfaction. As a result, this study focuses on the current enlightenment of homeworkers' work conditions and their consequences. The study presented a variety of findings based on current home-based employees.

In line with previous research, the results of the analysis provide support for a positive, direct relationship between home-based work and employee satisfaction (Schall, 2019; Ward, 2017).

It is evident from this study that in general, satisfaction levels are very high for domestic workers as they 
feel they are able to empower themselves with their responsibility to complete the tasks and get the job done. Many respondents commented on how homework allows them to be more motivated to complete work tasks so that they can spend more time with their families, which they would not be able to do if they worked full-time in line with (Kiss, 2020) findings.

The findings of the study work from home allow employees to have the best balance of work-life due to increased productivity, have significant levels of inspiration which recommended that they were happier, more committed, and have higher levels of work-life and work satisfaction. This supports the previous texts surrounding this topic as described by (Bloom, Nick \& Ying,2015).

This study helped define levels of employee satisfaction that home-based workers are more motivated to complete their day-to-day activities so that they have the flexibility and freedom they need to do non-workrelated activities. By staying active and focused domestic workers were able to find a good working life balance as they were able to design their working day around their family obligations and commitments in line with the findings of (Courtney,2020), (Regina ,2016) \& (Week , 2015). These results support the sub hypothesis from h1 to h3.

Hypothesis 4 stated that an employee's view of self-employment will enhance the relationship between work from home and work satisfaction, just as work from home will lead to higher self-esteem, which will be associated with higher job satisfaction. In line with previous research, the results of this study showed that visual independence completely affects the relationship between homework and work satisfaction (Schall, 2019 \& Ward, 2017).

However, one of the findings of the study is that there are certain limitations of working at home, which makes it difficult to recognize work risk and information security. Performance monitoring has been described as an important factor that can have a negative impact on satisfaction. In addition, sometimes the response is not guaranteed by the difficulty of monitoring performance that supports the h5 \& h6 statements. Communication problem $(\beta=0.582$, Sig $=0.635, \mathrm{p}<0.01)$ has no significant effect on employee satisfaction. These results challenge the earlier findings of (Kiss 2020).

The above factors have been shown to have a negative impact on employee satisfaction levels which may also have a negative impact on the employee's health balance, as described earlier in this study. However, there will always be negative aspects associated with any type of operational plan and it is important that organizations evaluate, adjust and find ways to deal with and overcome these issues.

Overall, it is clear from this study that there is a high level of self-esteem surrounding the home-wide practice, which was reflected in previous and more articles on the results of this study.

\subsection{Conclusion, Recommendation 6.1 Conclusion}

Work from home is a developing pattern in the present workplace. In this pandemic situation (Covid-19) work from home is a new concept in Bangladesh. Many organizations (both private \& public) introduce this in their workplace. Many have reported increased job engagement and satisfaction. Workers are enjoying the savings from eliminating costly commutes, not spending money on lunches, and not having to dress for work. People love the gained freedom to take care of home tasks during the day while still working, and the relief from being near to family and kids instead of at a job site. The main goal of the study was to investigate the manner in which work from home (WFH) impacts employees' satisfaction levels. The findings suggest that engaging in work from home increases employees' job satisfaction levels. More specifically, as the intensity of WFH increases, job satisfaction also increases. The results suggest that employees who engage in work from home have greater perceptions of flexibility \& autonomy, which leads them to become more content with their occupations. Also, the results imply that employees who engage in work from home have fewer work disruptions with family time, which also leads them to become more content with their occupations. Employees working from home have more control over their work environments \& personal life. WFH reduces the conflicts that typically occur between work and family life, further helps to manage children that create work-life balance. Lastly, the results suggest that employees, who engage in work from home, do so more frequently, which leads to greater satisfaction with their jobs.

\subsection{Recommendation}

This section intends to outline various recommendations that have been presented by the participants (that they have currently working from home).

As a suggestion, the organization may review the facilities to ensure that the employees have the correct facilities in place to allow them to work from home having strong ITS Infrastructure. Organizations could look at introducing a mentoring program whereby employees who currently work from home can share their experiences of how they manage their time and workload effectively. In addition, online collaboration should be introduced for reducing the feelings of isolation. The employees also asked have to create consistency in 
working hours. In the case of security, the organization should make a policy for ensuring official security and client confidentiality.

\section{References}

Bloom, N. (2015). Working from home can make people more productive. Just not during a pandemic. Retrieved 13 September 2020, from https://www.vox.com/2020/3/20/21187469/work-from-home-coronavirusproductivity-mental-health-nicholas-bloom.

Caramela, S. (2017). Communication technology and inclusion will shape the future of remote work. Business News Daily. Retrieved 20 November 2020, from https://www.businessnewsdaily.com/8156-future-ofremote-work.html.

Church,F. (2015). Gauging Perceived Benefits from 'Working from Home' as a Job Benefit. International Journal of Business and Economic Development. Vol. 3 Number 3 pp.81-89

Courtney, E. (2020). The Benefits of Working from Home beyond the Pandemic. Flexjob. Retrieved 13 September 2020, from https://www.flexjobs.com/blog/post/benefits-of-remote-work/.

Dawson, D. (2020). The Impact of a Work-at-Home Economy. Retrieved 13 September 2020, from http://www.circleid.com/posts/20200818-the-impact-of-a-work-at-home-economy/.

Dockery, A.,\&Bawa, s.(2014). Is Working from Home Good Work or Bad Work? Evidence from Australian Employees. AUSTRALIAN JOURNAL OF LABOUR ECONOMICS. Volume 17 Number 22014 pp $163-$ 190

Dizaho, Esther Kadarko; Salleh, Rohani; Abdullah, Azrai. (2017). Achieveing Work Life Balance Through Flexible Work Schedules and Arrangements. Global Business \& Management Research. Special Issue, Vol. 9, p455-465.

Ismail, F.,Hamsa, A., \&Mohamed, M. (2012). Factors That Influence Being Able to Telecommute St. Louis Fed. Stlouisfed.org. (2020). Retrieved 3 December 2020, fromhttps://www.stlouisfed.org/on-theeconomy/2020/january/factors-influence-ability-telecommute

Khan, M. (2019). What is the concept of work from home in India? - Quora. Quora.com. (2020). Retrieved 29 October 2020, from https://www.quora.com/What-is-the-concept-of-work-from-home-in-India.

KISS, M. (2020). Top 10 Advantages and Disadvantages of Working from Home .ClickTime. Retrieved 13 September 2020, from https://www.clicktime.com/blog/top-10-advantages-disadvantages-working-fromhome/.

Rupietta, K., \& Beckmann, M. (2016). Working from Home - What is the Effect on Employees' Effort? The Center of Business and Economics (WWZ), University of Basel.Retrieved 29 October 2020, from https://core.ac.uk/download/pdf/154352834.pdf.

Regina, W. (2016). Factors that Affect Job Satisfaction and Work Outcomes of Virtual Workers. Semanticscholar.org. Retrieved 13 December 2020, from https://www.semanticscholar.org/paper/Factorsthat-Affect-Job-Satisfaction-and-Work-of-Willis/dd367d581dcd413277b7f98dca2647048d826991.

Sarma, S.,\&Medhi, B. (2020). Work From Home Policy: A Definitive Guide For Managers. Vantage Circle HR Blog. (2020). Retrieved 29 October 2020, from https://blog.vantagecircle.com/work-from-home/.

Smith, A., Patmos, A., \& Pitts, J. (2018). Communication and Teleworking: A Study of Communication Channel Satisfaction, Personality, and Job Satisfaction for Teleworking Employees. SAGE Journals. Volume: 55 issue: 1, pp. 44-68

Reynolds, B. (2011). Telecommuting or Teleworking - What's the Difference?.FlexJobs Job Search Tips and Blog. Retrieved 3 December 2020, from https://www.flexjobs.com/blog/post/telecommuting-or-teleworkwhats-the-difference/.

Schall, M. A(2019), "The Relationship Between Remote Work and Job Satisfaction: The Mediating Roles of Perceived Autonomy, Work-Family Conflict, and Telecommuting Intensity" .Master's Theses. 5017. DOI: https://doi.org/10.31979/etd.2x82-58pg $\quad$ Retrieved $13 \quad$ September $2020, \quad$ from https://scholarworks.sjsu.edu/etd_theses/5017

Tabane, T. (2011). Job satisfaction in virtual and face-to-face teams for multiple generations in the workplace. $\begin{array}{lllll}\text { Repository.up.ac.za. } & \text { Retrieved } & \text { December } & \text { 2020, }\end{array}$ https://repository.up.ac.za/bitstream/handle/2263/27055/dissertation.pdf?sequence=1.

State University (2020). Benefits of Working from Home: 5 Reasons to Allow Employees to WFH. Retrieved 13 September 2020, from https://www.salary.com/articles/let-employees-work-from-home/.

Tolbert, Pamela S. and Simons, Tal, "The Impact of Working at Home on Career Outcomes of Professional Employees" (1994). CAHRS Working Paper Series.Paper 229. Retrieved 29 October 2020, from http://digitalcommons.ilr.cornell.edu/cahrswp/229

Ward, H. (2020). The Impact That Working from Home on the Overall Motivation and Performance Levels of Employees Working within a Banking Organization. Retrieved 13 September 2020, from http://trap.ncirl.ie/2827/1/hannahward.pdf. 
White, G. (2015). Working From Home: Awesome or Awful?. Retrieved 13 September 2020, from https:/www.theatlantic.com/business/archive/2015/10/is-working-from-home-workingtelecommute/411805/.

Zhang, J. (2016). The Dark Side of Virtual Office and Job Satisfaction. Vol.11, No.2 International Journal of Business and Management. Vol.11, No.2 pp. 41-47 